\title{
The Troubled Road to Repatriation in Central America: Lessons Learned by Refugees in Exile
}

\author{
Tanya Basok
}

In refugee assisting circles it is generally believed that the best solution to the refugee problem is voluntary repatriation. Similarly, many refugees living in exile nurture the hope that one day they will be able to return to the lands they were once forced to flee. This desire is especially strong if they face economic restrictions and administrative harassment in the country of asylum. When political conditions in the county of origin improve many refugees return. Often refugees get tired of waiting for the conditions to improve in their home countries and decide to go back in spite of persistent violations of human rights.

In Central America we have examples of both peaceful return and return before peace has been secured. The mass repatriation of Miskito Indians to the Atlantic coast of Nicaragua from Honduras was in response to ceasefire agreements with the Sandinista government and successful negotiations on limited Miskito autonomy. Alternatively, Salvadoreans returned from Honduras and Guatemalans from Mexico on an individual basis even when many were interrogated by the military, tortured, and killed by army bombs, gunfire, shrapnel, or mines (JRS 1991). Mass repatriation also started before safe return could be guaranteed. The 4,500 Salvadoreans from the Mesa Grande camp in Honduras announced their decision to repatriate in January 1987-a time when civil war was still being waged in $\mathrm{El}$ Salvador. They continued to make plans for their return in spite of reluctance by the Salvadorean government to meet basic their requirements necessary for return (ibid). Similarly, their compatriots in the Honduran camp of

\footnotetext{
Tanya Basok is an associate professor in the Department of Sociology and Anthropology, University of Windsor, Ontario.
}

Colomoncagua started their return in November 1989-before their return was officially approved and their safety guaranteed (Cagan and Cagan 1991, 130). Given the persistent harassment of Salvadorean refugees by the Honduran military and severe limitations on mobility within Honduras, it is hardly surprising that Salvadorean refugees chose to return. By comparison, Guatemalans in Mexico enjoyed better living conditions and safe asylum, yet the first group of 2,454 Guatemalans decided to repatriate to the province of Quiche on January 20, 1993. In this case, government promises did not protect those returning from helicopter surveillance or interrogations by the military (Gunn 1993, 10).

Refugees are less likely to feel homesick if economic and political conditions in the country of asylum are better than those in their own country. It is for this reason that most refugees who fled to Costa Rica have chosen to stay there. Recognizing this fact, on November 17, 1992, the President of Costa Rica, Rafael Calderon, signed a decree enabling Central American refugees to apply for resident status if they had been refugees for over two years (CIREFCA 1993).

Repatriation does not mean the restoration of former lives for refugees. During their absence both socio-economic and political conditions in their country will have changed. The longer refugees have stayed in asylum, the more changes they experience upon their return. If the country has been involved in a prolonged civil war, refugees return to destroyed roads, burned bridges, devastated fields, and people who bear physical and/or psychological scars. The repatriates are not the same as they were before they fled their country. The refugee experience leaves a significant imprint on them. I will outline some of the possible effects, both positive and negative, that life in asylum may have on the process of reintegration of Central American repatriates.

\section{Empowerment and Politicization}

Many refugees who fled their small, isolated villages in Central America find themselves in camps surrounded by people with similar flight-related experiences. In the face of adverse conditions, a common goal of survival creates a sense of unity among them. In camps, refugees form committees to run their own affairs. In exile, their political consciousness is also raised as refugees try to interpret the political conditions which forced them to flee their homelands. Since their return is premised upon the improvement of human rights in their country, they become keenly aware of the political developments there. Political discussions are often stimulated and directed by members of various political parties. Even literacy classes, music and other forms of artistic expression become statements of protest against violence and injustice in their country.

Refugees also learn that any political change or resistance to change requires collective action. And while it is difficult to influence political processes in the country of origin from a refugee camp, conditions prevailing inside the camps and/or certain policies towards refugees in the asylum country can be manipulated through such collective action. The best known example being the Salvadorean refugees in the Colomoncagua camp in Honduras who successfully engaged in a number of protest activities, including resistance to relocation, opposition to attacks carried out on refugees by the Honduran army, demands for more protection from UNHCR, and a hunger strike to protest increased cuts in food assistance and poor medical services (Cagan and Cagan 1991, 45). 
Refugees in other Central American camps have learned that they too can partly control their lives through organized activities aimed at making their pleas known to the international community. Because their camps are frequently visited by representatives of international agencies, refugees have learned to use these contacts to make their messages known to the outside world and to exert pressure on governments. They have also learned that when their demands are backed by the international community, they can negotiate with the government of their home country. Both Guatemalan and Salvadorean repatriates engaged in lengthy negotiations with their respective governments demanding that security conditions and access to land be guaranteed before they returned. Once empowered, repatriates may continue to use collective action to meet their demands upon their return.

Some Nicaraguan refugees in Honduras were kidnapped by the Contras and forced to fight on the Contra side. Others, living in refugee camps, had to provide food and other forms of assistance to the Contra fighters (Ambos 1987). The extent to which these refugees became ideological supporters of the Contras may have influenced their choice to become involved in Nicaraguan politics upon their repatriation.

\section{New Skills and Knowledge}

In the countries of asylum, international NGOs provide funds for the education of adult and children refugees. Adult literacy classes received by many refugees in exile give them an edge over their compatriots who stayed behind. Refugee children who, thanks to UNHCR emergency aid, are not pressured to work in order to contribute to the family income, can afford to attend classes. In addition, many adult and adolescent refugees receive technical and business administration training courses that they may find useful upon return. Also, some indigenous refugees have improved their Spanish language skills when forced to share camps with other refugees who do not understand their language.
Refugees living in camps and those placed in rural projects also learn that there are certain advantages and disadvantages in cooperative work. Governmental and non-governmental agencies providing assistance to refugees often try to encourage them to work collectively. In many cases, these attempts are resisted by refugees who prefer producing individually (Aguayo et al. 1987). In Costa Rica, for instance, people who were forced to work in cooperatives found it difficult to maintain peaceful inter-personal relations. Conflicts over power, levels of remuneration, and ideology, created tensions and led to the eventual disintegration of many projects (Basok 1993a). As I have argued elsewhere, (Basok 1993b) in the urban environment, cooperative forms of production may hinder the economic viability of these small enterprises (ibid). Yet, for agricultural producers there are great advantages in collective marketing. And this is the lesson that many refugees who were involved in rural projects may bring back with them when they return.

\section{"Dependency Syndrome"}

Having to depend on emergency aid for a prolonged period of time produces what has been termed a "dependency syndrome" (Clark 1986) among refugees. Even those who are placed in productive projects often have their incomes supplemented by emergency aid. They know that if problems related to production or marketing arise, they will still have their basic needs met by various agencies assisting them.

Upon their return, repatriates initially receive financial support from international NGOs but they are expected to quickly become self-sufficient. Of course, without limitations. on their mobility and unrestricted access to casual employment opportunities, repatriates are in a better position to fend for themselves than they were in the country of asylum. Yet repatriates may still find it difficult to sever their dependency on international aid agencies. This was the case with repat- riates from Colomoncagua (Cagan and Cagan 1991,163) and it is possible that other repatriates will have similar experiences.

\section{Guilty Conscience}

Finally, social reintegration of repatriates may be affected by the degree to which they carry a guilty conscience due to the fact that they escaped while their friends and relatives stayed behind and endured the burden of physical abuse and economic devastation. Many researchers have reported high levels of anxiety among refugees who blame themselves for the humiliation, harassment, torture and even death of those they left behind. Of course, refugees often receive psychological treatment both inside camps and outside. With time, some of this anxiety may dissipate. Yet, it is possible that upon their return, refugees are once again reminded of the hardship suffered by their loved ones who did not manage to escape; reawakening feelings of guilt.

\section{References}

Aguayo, S., Christensen, H., O'Dogherty, L., and Varese, S. 1987. Social and cultural conditions and prospects of Guatemalan refugees in Mexico. Geneva: UN Research Institute for Social Development.

Ambos, Kai. 1987. The Central American Refugee Crisis: A Comparative Study of the Refugee Situation and Refugee Policies in Costa Rica, Honduras and Nicaragua. Oxford: Refugee Studies Programme, University of Oxford.

Basok, Tanya. 1993a. Keeping Heads Above Water: Salvadorean Refugees in Costa Rica. Montreal: McGill-Queens University Press.

_. 1993b. "Individual, household and cooperative production: The case of Salvadorean refugees in Costa Rica." Canadian Journal of Latin American and Caribbean Studies 18(35): 19-40.

Cagan, Beth and Cagan, Steve. 1991. This Promised Land, El Salvador. London: Rutgers University Press.

Clark, Lance. 1986. "Dependency syndrome: Another look." Refugees Magazine 29.

Gunn, Joe. 1993. "The long road home begins." Refugee Update (Spring).

International Conference on Central American Refugees (CIREFCA). 1989. Guatemala, May.

Jesuit Refugee Service. 1991. Increased Faith? Repatriations and Deportations to El Salvador, a Human Rights Study. Canada. a 